\title{
Intrauterine Twin Discordancy and Partial Postnatal Catch-up Growth in a Girl with a Pathogenic IGF1R Mutation
}

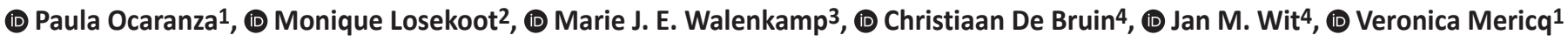 \\ 1 University of Chile Faculty of Medicine, Institute of Maternal and Child Research, Santiago, Chile \\ 2 Leiden University Medical Center, Department of Clinical Genetics, Leiden, The Netherlands \\ ${ }^{3}$ Emma Children's Hospital, Amsterdam University Medical Center, Vrije Universiteit Amsterdam, Department of Pediatric Endocrinology, \\ Amsterdam, The Netherlands \\ ${ }^{4}$ Leiden University Medical Center, Department of Pediatrics, Leiden, The Netherlands
}

\begin{abstract}
What is already known on this topic?
IGF1R mutations cause prenatal and postnatal decrease in linear growth. This mutation (p.Glu1050Lys) has been tested in vitro in fibroblasts which showed a decrease in phosphorylation of STAT5, a protein that, when activated, acts as a transcription factor in the nucleus.
\end{abstract}

\section{What this study adds?}

The effect of this mutation on intrauterine growth was tested for the first time in discordant twins. The affected girl's weight decreased by $36 \%$ and her length by $12 \%$. This case highlights that intrauterine twin discordancy can occur in some patients carrying IGF1R mutations.

\begin{abstract}
Objective: Insulin like growth factors-1 (IGF-1) is essential for normal in utero and postnatal human growth. It mediates its effects through the IGF-1 receptor (IGF1R), a widely expressed cell surface tyrosine kinase receptor. The aim of the study was to analyze pre- and post-natal growth, clinical features and laboratory findings in a small for gestational age (SGA) girl in whom discordant postnatal growth persisted and her appropriate for gestational age (AGA) brother.

Methods: A girl born with a low weight and length [-2.3 and -2.4 standard deviation (SD) Score (SDS), respectively] but borderline low head circumference (-1.6 SD) presented with a height of -1.7 SDS, in contrast to a normal height twin brother (0.0 SDS). IGF-1 resistance was suspected because of elevated serum IGF-1 levels.

Results: Sequencing revealed the presence of a previously described pathogenic heterozygous mutation (p.Glu1050Lys) in the SGA girl which was not present in the parents nor in the AGA twin brother.

Conclusion: The pathogenic IGF1R mutation in this girl led to intrauterine growth retardation followed by partial postnatal catch-up growth. Height in mid-childhood was in the lower half of the reference range, but still 1.7 SD shorter than her twin brother.

Keywords: Insulin-like growth factor type-1, insulin-like growth factor type-1 receptor, small for gestational age, postnatal growth, intrauterine discordancy
\end{abstract}




\section{Introduction}

Insulin like growth factors (IGFs) are essential for intrauterine and postnatal growth and development (1). The mitogenic effects of IGF-1 are mediated through the IGF-1 receptor (IGF1R), a cell surface tyrosine kinase receptor encoded by IGF1R (15q26.3) (2). Synthesized as a single polypeptide precursor, the IGF1R undergoes proteolytic cleavage into $\alpha$ - and $\beta$-chains and forms a tetramer $\left(\alpha_{2} \beta_{2}\right)$, with the extracellular $\alpha_{2}$-subunits involved in ligand binding and the $\beta_{2}$-subunits carrying intrinsic tyrosine kinase activities (2). Ligand association leads to IGF1R autophosphorylation and activation of multiple downstream signaling pathways (3). This signaling results in fetal somatic growth, whereas postnatal somatic growth is achieved through the synergistic interaction of growth hormone (GH) and IGFs, among other factors (4).

The role of IGFs and their receptors in growth and development was first studied in animal models in which the invalidation of the Igf1 and Igf1r genes in mice causes pre- and post-natal growth retardation (5). Later, genetic studies in short children showed that absent or decreased expression of IGF-1 leads to severe pre- and post-natal growth failure, and microcephaly $(6,7,8)$, while heterozygous (or compound heterozygous hypomorphic) mutations or deletions of IGF1R lead to a variable degree of pre- and postnatal growth failure and microcephaly $(9,10,11)$.

Intrauterine growth retardation (IUGR) is not a rare condition and can lead to a small body size for gestational age (SGA) (12). It can be caused by maternal, placental or fetal factors. Approximately $90 \%$ of children born SGA show catch-up growth in the first years of life $(13,14)$. In these children no further diagnostic tests are carried out. In children born SGA with persistent short stature multiple genetic causes have been detected (15)

We report a twin girl born SGA with partial catch-up growth, but still 1.7 standard deviation (SD) shorter than her appropriate for gestational age (AGA) born twin brother. Her serum IGF-1 level was unexpectedly elevated, due to a previously described pathogenic mutation in IGF1R (c.3148G > A, p.Glu1050Lys).

\section{Methods}

\section{Subjects}

Informed consent was obtained from the family to participate and provide samples (DNA, whole blood), in compliance with the Institutional Ethics Committee at San Borja-Arriarán's Hospital (Santiago, Chile).

\section{Sample Procurement}

Genomic DNA was isolated from peripheral blood from the patient, her sibling and from both parents. The samples were sent to the Laboratory for Diagnostic Genome Analysis, Department of Clinical Genetics at the Leiden University Medical Center (LUMC) for routine genetic testing of IGF1R. Targeted Sanger sequencing of the complete coding region exon 1-21 including intron/ exon boundaries (NM_000875.3) was performed as previously reported $(10,16)$. Multiplex ligation-dependent probe amplification (MLPA) assay (MRC Holland kit P217-B2) containing probes for IGF1R exon 1-21 was performed for the detection of deletions or duplications (16).

\section{Statistical Analysis}

Comparisons between groups were not performed in this study.

\section{Results}

\section{Clinical Presentation of the Index Patient}

The Chilean female index patient was part of a bichorial biamniotic twin, born after a pregnancy interrupted due to premature membrane rupture and metrorrhagia. The patient showed in utero growth discordancy at week 21 and was born SGA at 33 weeks of gestational age, with a birth weight of $1.48 \mathrm{~kg}$ [-2.4 SD score (SDS)] (17), a birth length of $39 \mathrm{~cm}(-2.4$ SDS) and a head circumference of $29.5 \mathrm{~cm}$ (-1.6 SDS) (Figure 1A). During her first days of life, she was hospitalized for gastric distress. Several episodes of gastrooesophageal reflux with and without cyanosis were reported after hospitalization.

The parents were not consanguineous. Paternal and maternal heights were $176.9 \mathrm{~cm}(-0.1 \mathrm{SDS})$ and $157.9 \mathrm{~cm}$ $(-1.0$ SDS), respectively, with a target height of -0.45 SDS (18). The father reported normally timed puberty and the mother's pubertal development was slightly delayed (menarche 14 years). Paternal grandfather and -mother had a height of $170 \mathrm{~cm}(-0.9 \mathrm{SDS})$ and $165 \mathrm{~cm}(0.4 \mathrm{SDS})$, and maternal grandparental heights were $162 \mathrm{~cm}(-2.1$ SDS) and $157 \mathrm{~cm}$ (-1.0 SDS), respectively (Figure 2).

The patient was referred to the pediatric endocrine unit for evaluation of short stature at age 1.25 years, because of postnatal growth discordancy with her twin brother (Table 1). Height to arm span ratio was abnormal $(\geq 1.0)$, weight $6.87 \mathrm{~kg}(-2.8 \mathrm{SDS}$ for age), weight for height -2.2 SDS (19), and head circumference $44.8 \mathrm{~cm}$ (-1.3 SDS). Physical examination revealed normal body proportions and a small midface, mild frontal bossing, a thin upper lip, 
and mild hypertelorism. Bone age was delayed by three months. A normal female karyotype (46 XX) was found. Serum IGF-1 concentration was high $(194 \mathrm{ng} / \mathrm{mL}$; reference range $(\mathrm{RR})<131 \mathrm{ng} / \mathrm{mL}$ ) and IGFBP-3 levels in the upper normal range $(3.1 \mathrm{mg} / \mathrm{L} ; \mathrm{RR}=1.1-3.6 \mathrm{mg} / \mathrm{L})$. Independent walking was achieved at 1.25 years. Her appetite was poor and selective.

Over the subsequent eight years she visited the clinic several times (Table 1). Psychomotor development was normal. Height remained below -2 SDS up to three years of age and then increased (Figure 1B). Bone age at 3.75 years was delayed but identical to chronological age by 6.33 years. At age 8.92 years she was prepubertal and a small diffuse goiter was noted, confirmed by the finding of a small thyroid cyst at ultrasound. Thyroid function was normal during follow-up. Over the years, her circulating IGF-1 levels and IGFBP-3 concentrations remained high (Table 1).

\section{The Patient's Twin Brother}

The male twin brother of the index patient was born at 33 weeks of gestational age with a weight of $2.0 \mathrm{~kg}$ and length of $44 \mathrm{~cm}$. Growth data are shown in Table 1 . At 1.75 years of age, his height was $83 \mathrm{~cm}$ and weight was $13.3 \mathrm{~kg}$ (Figure 1C). Thereafter his height SDS increased to close to the reference mean (Table 1) and was slightly above conditional target height SDS, and remained stable afterwards (Figure 1D). He has no associated morbidities nor dysmorphic features (Figure 3).

\section{Genetic Studies}

Since the clinical and biochemical characteristics of the index patient were consistent with IGF-1 resistance which could be caused by a deletion or an inactivating mutation in the gene encoding IGF1R, targeted sequencing and MLPA was performed for IGF1R on genomic DNA from whole blood from the index patient. Sequence analysis showed a heterozygous nucleotide substitution at position 3148 (c.3148G > A), changing glutamic acid to lysine at position 1050 of the mature IGF1R protein (p.Glu1050Lys). This heterozygous mutation was not encountered in the twin brother nor in either parent. It was confirmed by PP 16 analysis that the index patient was the daughter of this couple.

\section{Discussion}

In this study, we report a patient who presented with preand post-natal growth retardation resulting from a de novo heterozygous IGF1R mutation in exon 16 (c.3148G > A, p.Glu1050Lys). Substitution of this highly conserved amino acid residue, located in the intracellular tyrosine kinase domain, is associated with a change in charge of the amino acid and in silico analysis predicts inactivation of the IGF1R leading to a partial resistance to IGF-1. This mutation was not identified in the patient's twin AGA born normalstatured brother nor in other family members.

Fetal growth and development are influenced by maternal, placental and fetal factors (1). A variety of maternal and utero-placental factors may constrain the growth of the

\begin{tabular}{|c|c|c|c|c|c|c|c|c|c|c|c|}
\hline \multirow[b]{2}{*}{$\begin{array}{l}\text { Age } \\
\text { (years) }\end{array}$} & \multicolumn{7}{|c|}{ Index patient } & \multicolumn{4}{|l|}{ Sibling } \\
\hline & $\begin{array}{l}\text { Height } \\
\mathrm{cm} \text { (SDS) }\end{array}$ & $\begin{array}{l}\text { Weight } \\
\text { kg (SDS) }\end{array}$ & $\begin{array}{l}\text { BMI } \\
\text { (SDS) }\end{array}$ & $\begin{array}{l}\mathrm{HC} \\
\mathrm{cm} \text { (SDS) }\end{array}$ & $\begin{array}{l}\text { Bone } \\
\text { age }\end{array}$ & $\begin{array}{l}\text { IGF } 1 \\
\mathrm{ng} / \mathrm{mL} \text { (RR) }\end{array}$ & $\begin{array}{l}\text { IGFBP-3 } \\
\text { mg/L (RR) }\end{array}$ & $\begin{array}{l}\text { Height } \\
\mathrm{cm} \text { (SDS) }\end{array}$ & $\begin{array}{l}\text { Weight } \\
\text { kg (SDS) }\end{array}$ & $\begin{array}{l}\text { BMI } \\
\text { (SDS) }\end{array}$ & $\begin{array}{l}\mathrm{HC} \\
\mathrm{cm} \text { (SDS) }\end{array}$ \\
\hline $\begin{array}{l}\text { Birth } \\
\text { data }\end{array}$ & $\begin{array}{l}39 \\
(-2.5)\end{array}$ & $\begin{array}{l}1.48 \\
(-2.4)\end{array}$ & & $\begin{array}{l}29.5 \\
(-1.6)\end{array}$ & NA & NA & NA & $\begin{array}{l}44 \\
(0.0)\end{array}$ & $\begin{array}{l}2.0 \\
(-0.6)\end{array}$ & & NA \\
\hline 1.25 & $\begin{array}{l}69.4 \\
(-3.0)\end{array}$ & $\begin{array}{l}6.87 \\
(-2.8)\end{array}$ & $\begin{array}{l}14.3 \\
(-1.3)\end{array}$ & $\begin{array}{l}44.8 \\
(-1.3)\end{array}$ & 1 year & $194(<131)$ & $\begin{array}{l}3.1 \\
(1.1-3.6)\end{array}$ & NA & $\begin{array}{l}10.7 \\
(0.2)\end{array}$ & NA & $\begin{array}{l}48 \\
(0.9)\end{array}$ \\
\hline 3.08 & $\begin{array}{l}86.2 \\
(-2.1)\end{array}$ & $\begin{array}{l}10 \\
(-3.5)\end{array}$ & $\begin{array}{l}13.5 \\
(-2.3)\end{array}$ & NA & NA & $269(<289)$ & $\begin{array}{l}4.3 \\
(<4.3)\end{array}$ & NA & NA & $\mathrm{NA}$ & NA \\
\hline 3.75 & NA & $\mathrm{NA}$ & NA & $\mathrm{NA}$ & 3 year & NA & NA & NA & NA & NA & NA \\
\hline 4.25 & $\begin{array}{l}95.5 \\
(-1.6)\end{array}$ & $\begin{array}{l}13.1 \\
(-1.9)\end{array}$ & $\begin{array}{l}14.4 \\
(-0.8)\end{array}$ & NA & NA & $330(<289)$ & $\begin{array}{l}4.5 \\
(<4.3)\end{array}$ & $\begin{array}{l}104.8 \\
(0.2)\end{array}$ & $\begin{array}{l}20.9 \\
(1.6)\end{array}$ & $\begin{array}{l}19.0 \\
(2.4)\end{array}$ & NA \\
\hline 4.75 & NA & NA & NA & NA & 4 year & NA & NA & NA & NA & NA & NA \\
\hline 6.33 & $\begin{array}{l}109 \\
(-1.6)\end{array}$ & $\begin{array}{l}17 \\
(-1.7)\end{array}$ & $\begin{array}{l}14.3 \\
(-0.7)\end{array}$ & $\begin{array}{l}49 \\
(-1.7)\end{array}$ & 6.5 year & $417(<286)$ & NA & $\begin{array}{l}118.3 \\
(0.2)\end{array}$ & $22(0.1)$ & $\begin{array}{l}15.7 \\
(0.2)\end{array}$ & $\begin{array}{l}53.5 \\
(1.0)\end{array}$ \\
\hline 8.92 & $\begin{array}{l}122.0 \\
(-1.8)\end{array}$ & $\begin{array}{l}21 \\
(-2.1)\end{array}$ & $\begin{array}{l}14.1 \\
(-1.3)\end{array}$ & NA & NA & NA & NA & $\begin{array}{l}132.2 \\
(-0.1)\end{array}$ & $\begin{array}{l}37.7 \\
(1.4)\end{array}$ & $\begin{array}{l}21.6 \\
(1.7)\end{array}$ & NA \\
\hline
\end{tabular}


A
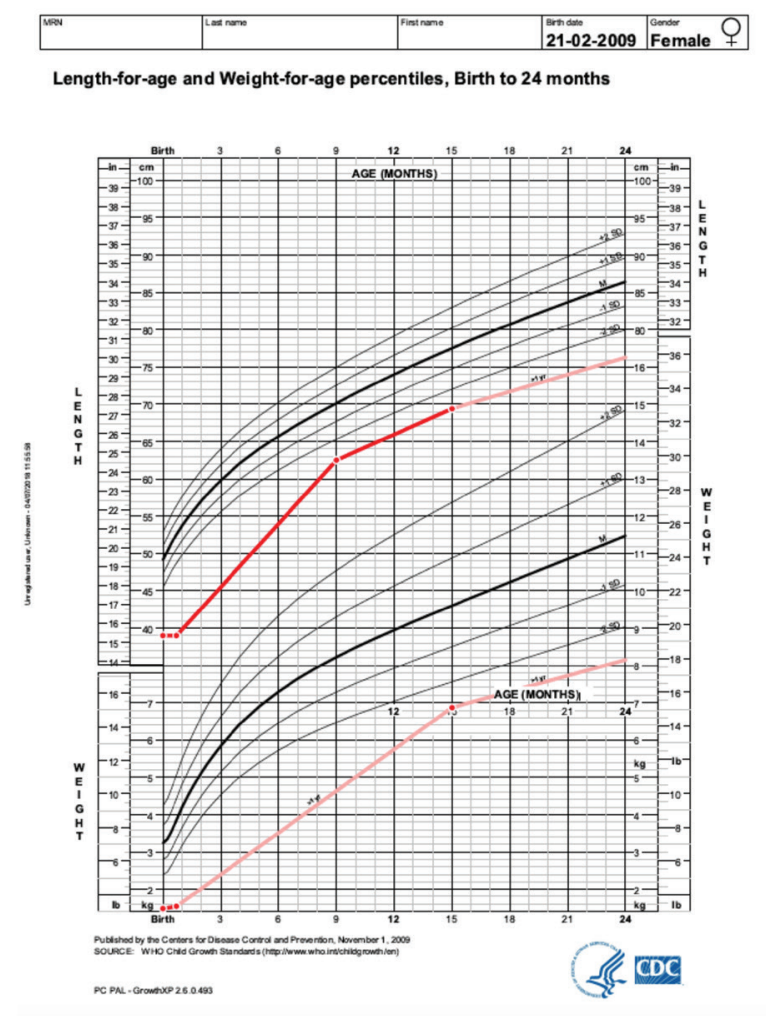

C
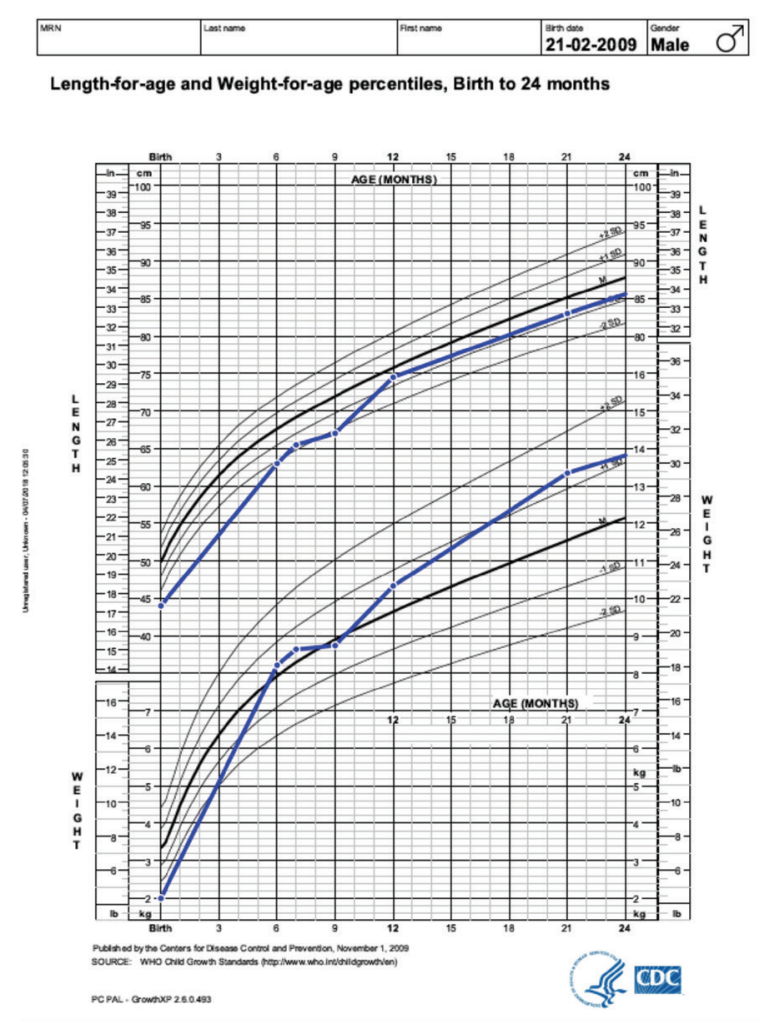

B

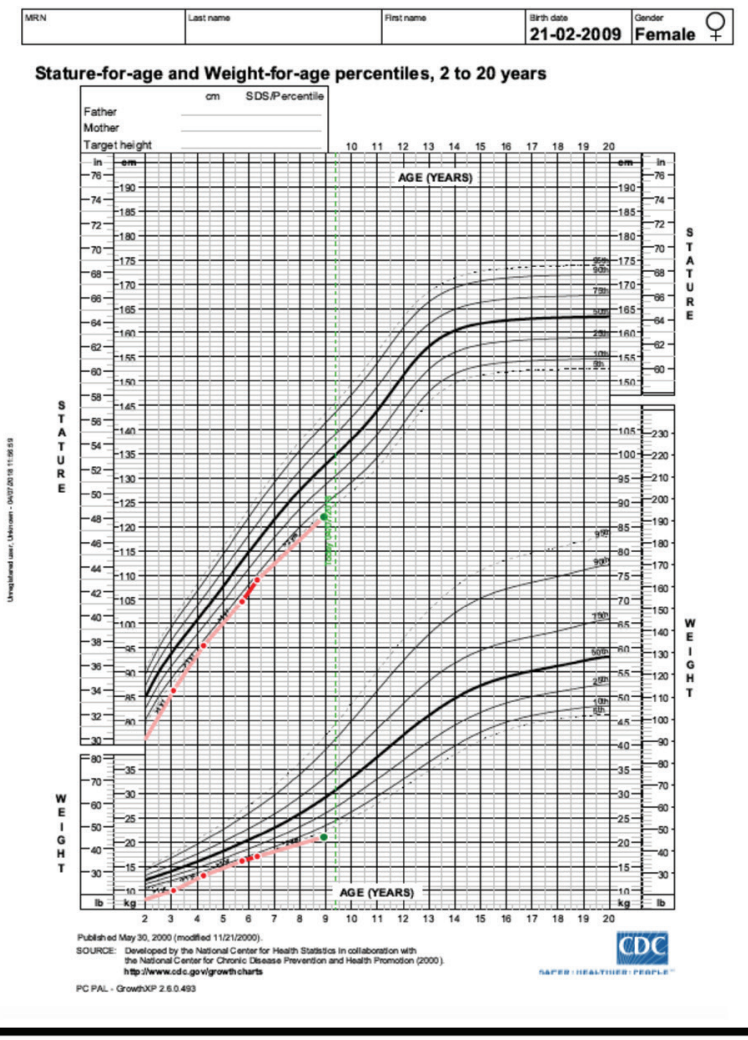

D
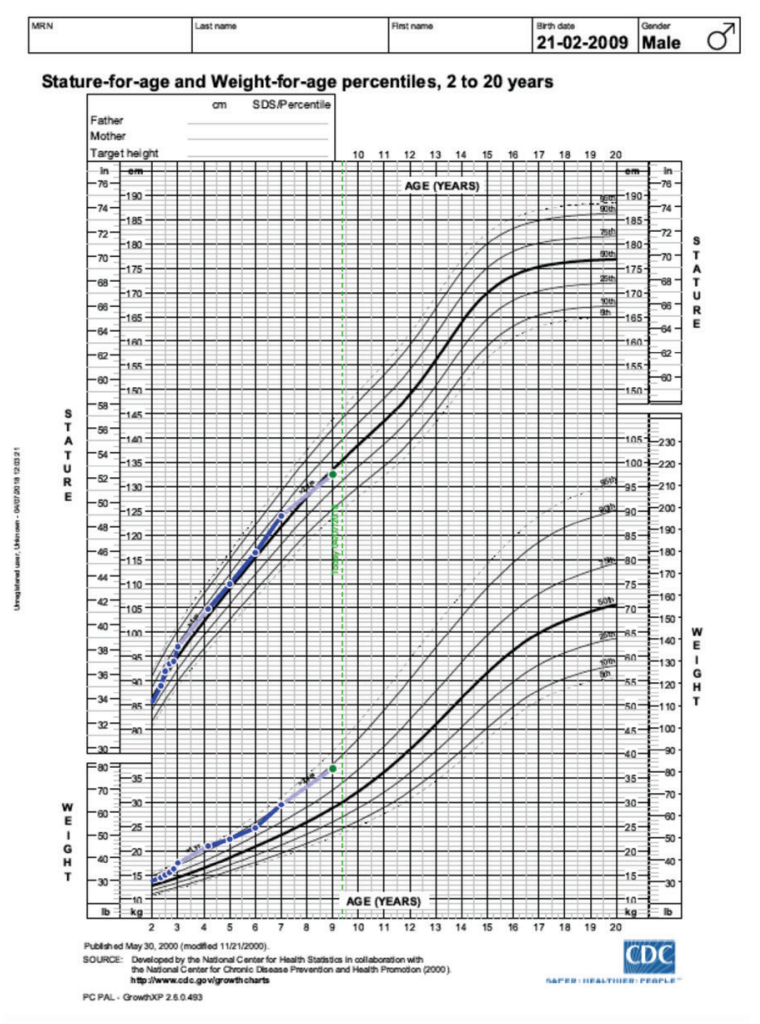

Figure 1. Growth chart of the patient (A) and her twin brother (B). Growth charts of the patient carrying the mutation (C) and (D) growth charts of the normal statured brother 


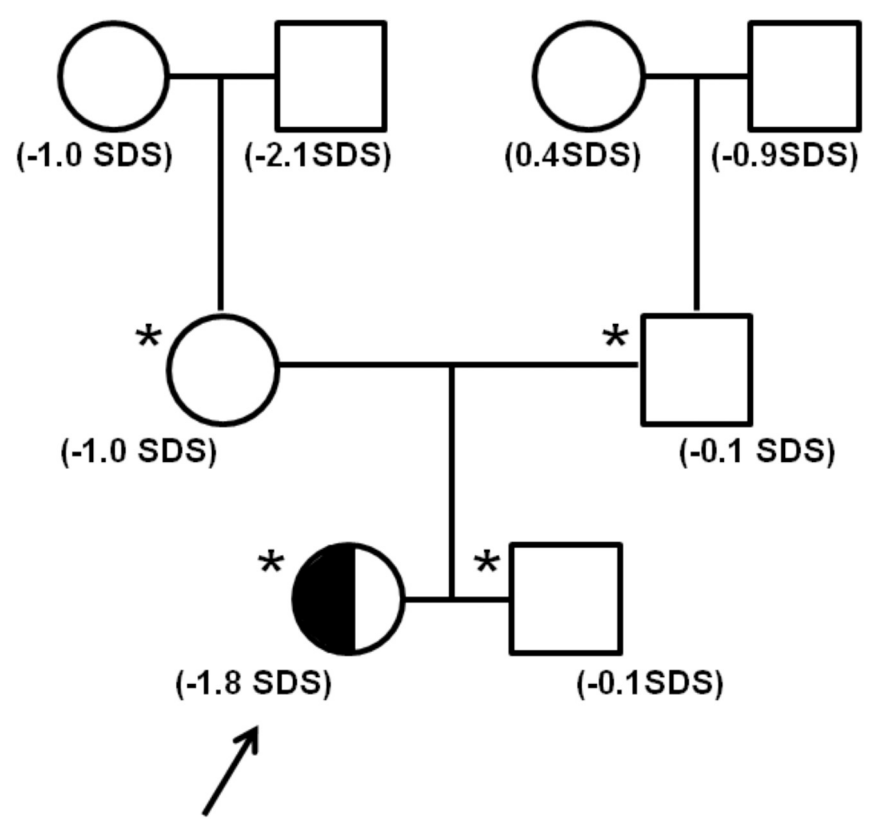

Figure 2. Pedigree of the index patient with the IGFIR mutation. Height standard deviation score is indicated in brackets and persons who were checked for the IGFIR mutations are indicated $\left({ }^{*}\right)$

SDS: standard deviation score

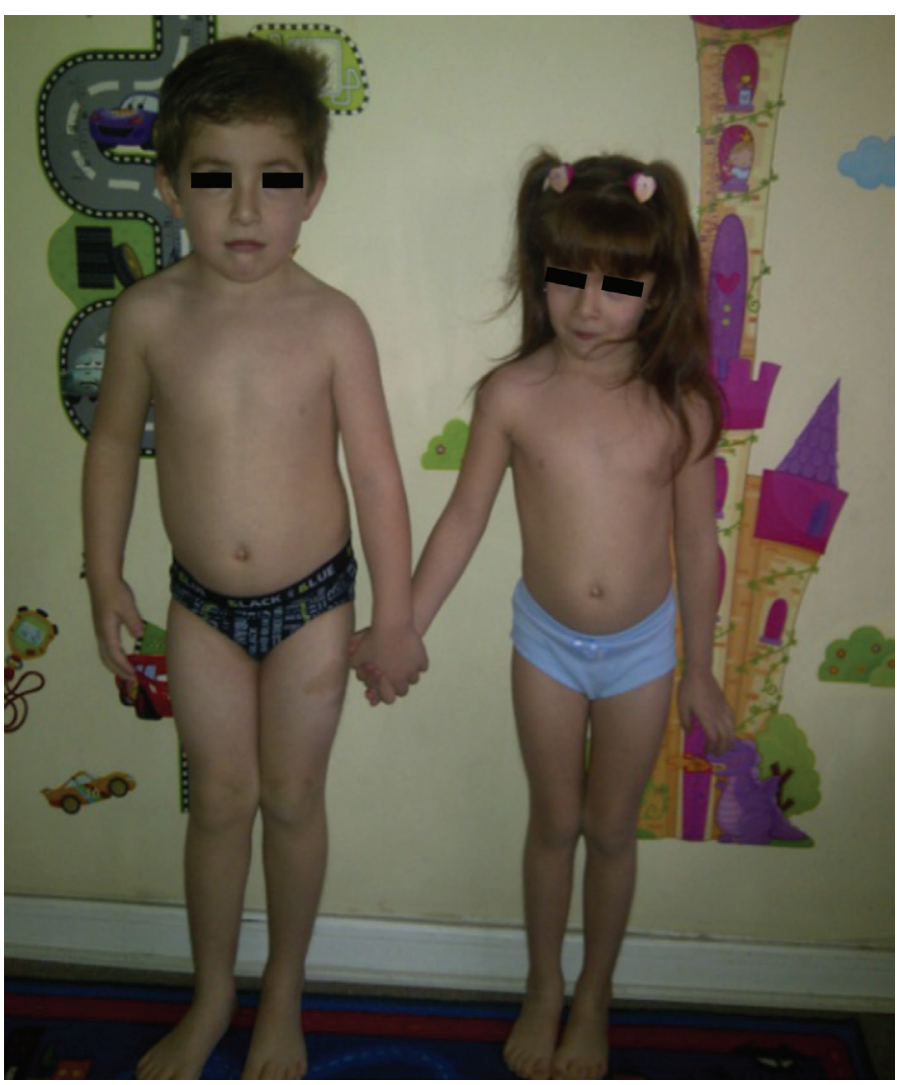

Figure 3. Picture of the twins taken in July 2014 fetus. In this interesting experiment of nature the role of maternal and placental factors are well controlled and separated from the role of fetal factors. A series of elegant investigations in mice, complemented by case studies in humans, have convincingly demonstrated the critical role of the IGF system in pre- and post-natal growth (5). Targeted disruption of the gene encoding Igf- 2 in mice resulted in a 40 percent reduction in fetal growth with normal postnatal growth, demonstrating the important role of IGF-2 in intrauterine growth. Disruption of the gene for Igf-1 led to a similar decrease in birth weight but also led to persistent postnatal growth failure. Furthermore, deletion of the gene encoding Igf $1 \mathrm{r}$, which mediates the growth-promoting actions of both Igfs, resulted in birth weights that were only 45 percent of normal and these mice generally died within hours after birth from respiratory insufficiency due to muscular hypoplasia (5). The relevance of these findings for human growth was supported by reports on humans. Homozygous mutations of IGF-1 were found in a few patients presenting with severe pre- and post-natal growth failure, microcephaly and deafness $(6,7)$. Several reports have been published of patients with IGF-1 resistance due to molecular defects in the IGF1R who present with a variable degree of pre-and post-natal growth retardation (9).

Short stature is a common problem confronting pediatric endocrinologists. After exclusion of systemic or skeletal diseases or overt hormonal deficiencies, clinicians are often unable to provide a definitive diagnosis for the etiology of an individual patient's short stature. An important clue for the cause of short stature is to register whether prenatal growth was normal or reduced. We suspected a mutation within the IGF-1 signaling cascade because of the persistent short stature in our patient and the high IGF-1 levels. Our hypothesis led us to the detection of a de novo heterozygous mutation of IGF1R in exon 16, resulting in the replacement of a Glu residue at position 1050 by a Lys residue. So far, mutations in IGF1R were almost always reported to result in IUGR, and postnatal catchup growth had not been documented. Aberrant IGF1R expression is described to lead to IGF1R haploinsufficiency $(20,21)$, disturbed processing of the proreceptor $(22,23)$, decreased ligand binding (24), abrogated IGF1R tyrosine kinase activity and reduced receptor autophosphorylation $(10,25,26)$.

In line with the previously reported adult patient (with a birth weight and length of -2.1 and -0.3 SDS, respectively, and a height SDS of -3.3 at presentation, and an adult head circumference SDS of -3.0), the mutation led to a clinically significant prenatal and postnatal growth failure, though 
postnatal growth of our patient is less affected compared to almost all cases with IGF1R haploinsufficiency described to date. This mutation was also associated with microcephaly, but it did not affect intellectual development. Our patient was reported to have feeding problems during the first year of life and poor appetite, which previously has been associated with the same and other IGF1R mutations (10). This mutation was not present in her twin brother and parents, who all have normal stature. Our results provide strong evidence that this variant is likely to be the underlying cause of the IUGR and mild postnatal short stature observed in this patient.

Most of the IGF1R mutations have been described in children born SGA. The first human IGF1R defects were described by Abuzzahab et al (9) in 2003 and only a few compound heterozygous cases have been described thereafter $(9,27)$. Most of the described cases are heterozygous carriers of IGF1R mutations $(10,20,21,22,23,25,26,28,29,30,31,32,33$, 34). To date only two single patients carrying a homozygous mutation have been described $(35,36)$. The phenotype is variable, presumably depending on the impact of the mutation on the function of the IGF1R. The most common feature described in the reported patients included IUGR $(11,37)$, postnatal growth failure and microcephaly $(11,37,38)$.

\section{Study Limitations}

The affected Glu residue at position 1050, is located in the strongly conserved serine-threonine/tyrosine-protein kinase catalytic domain. A study limitation was the absence of functional studies, as fibroblasts from skin biopsies were not available. However, functional analysis of fibroblasts from a previously described patient with the same mutation showed a marked reduction of autophosphorylation of the IGF1R and of activation of PKB/Akt upon a challenge with IGF-1. Furthermore, $[3 \mathrm{H}]$ thymidine incorporation in that patient's cells after a challenge with a dose range of IGF-1 in comparison with a panel of fibroblast cultures of eight non-growth-retarded individuals (controls) showed a $50 \%$ reduction (10).

\section{Conclusion}

In conclusion, we describe a discordant pair of twins in whom the effect of this IGF1R mutation in the context of a similar intrauterine environment is unmasked. This clinical observation shows that while it is assumed that most patients carrying IGF1R mutations remain short postnatally, partial catch-up growth can occur, possibly related to increased GH and IGF-1 secretion.

\section{Ethics}

Ethics Committee Approval: It is in compliance with the Institutional Ethics Committee at San Borja-Arriarán's Hospital (Santiago, Chile).

Informed Consent: It was obtained from the family to participate and provide samples (DNA, whole blood).

Peer-review: Internally peer-reviewed.

\section{Authorship Contributions}

Surgical and Medical Practices: Veronica Mericq, Concept: Veronica Mericq, Jan M. Wit, Design: Veronica Mericq, Jan M. Wit, Data Collection or Processing: Monique Losekoot, Veronica Mericq, Analysis or Interpretation: Paula Ocaranza, Monique Losekoot, Literature Search: Paula Ocaranza, Veronica Mericq, Marie J. E. Walenkamp, Christiaan De Bruin, Writing: Paula Ocaranza, Veronica Mericq, Jan M. Wit.

Financial Disclosure: This work did not receive any specific grant from any funding agency in the public, commercial or not-for-profit sector.

\section{References}

1. Murphy VE, Smith R, Giles WB, Clifton VL. Endocrine regulation of human fetal growth: the role of the mother, placenta, and fetus. Endocr Rev 2006;27:141-169. Epub 2006 Jan 24

2. Adams TE, Epa VC, Garrett TP, Ward CW. Structure and function of the type 1 insulin-like growth factor receptor. Cell Mol Life Sci 2000;57:1050-1093.

3. LeRoith D, Werner H, Beitner-Johnson D, Roberts CT Jr. Molecular and cellular aspects of the insulin-like growth factor I receptor. Endocr Rev 1995; 16:143-163

4. Baron J, Sävendahl L, De Luca F, Dauber A, Phillip M, Wit JM, Nilsson O. Short and tall stature: a new paradigm emerges. Nat Rev Endocrinol 2015;11:735-746. Epub 2015 Oct 6

5. Liu JP, Baker J, Perkins AS, Robertson EJ, Efstratiadis A. Mice carrying null mutations of the genes encoding insulin-like growth factor I (Igf-1) and type 1 IGF receptor (Igf1 r). Cell 1993;75:59-72.

6. Woods KA, Camacho-Hübner C, Savage MO, Clark AJ. Intrauterine growth retardation and postnatal growth failure associated with deletion of the insulin-like growth factor I gene. N Engl J Med 1996;335:13631367

7. Walenkamp MJ, Karperien M, Pereira AM, Hilhorst-Hofstee Y, van Doorn J, Chen JW, Mohan S, Denley A, Forbes B, van Duyvenvoorde HA, van Thiel SW, Sluimers CA, Bax JJ, de Laat JA, Breuning MB, Romijn JA, Wit JM. Homozygous and heterozygous expression of a novel insulin-like growth factor-I mutation. J Clin Endocrinol Metab 2005;90:2855-2864. Epub 2005 Mar 15

8. Netchine I, Azzi S, Houang M, Seurin D, Perin L, Ricort JM, Daubas C, Legay C, Mester J, Herich R, Godeau F, Le Bouc Y. Partial primary deficiency of insulin-like growth factor (IGF)-I activity associated with IGF1 mutation demonstrates its critical role in growth and brain development. J Clin Endocrinol Metab 2009;94:3913-3921. Epub 2009 Sep 22

9. Abuzzahab MJ, Schneider A, Goddard A, Grigorescu F, Lautier C, Keller E, Kiess W, Klammt J, Kratzsch J, Osgood D, Pfäffle R, 
Raile K, Seidel B, Smith RJ, Chernausek SD; Intrauterine Growth Retardation (IUGR) Study Group. IGF-I receptor mutations resulting in intrauterine and postnatal growth retardation. N Engl J Med 2003;349:2211-2222

10. Walenkamp MJ, van der Kamp HJ, Pereira AM, Kant SG, van Duyvenvoorde HA, Kruithof MF, Breuning MH, Romijn JA, Karperien M, Wit JM. A variable degree of intrauterine and postnatal growth retardation in a family with a missense mutation in the insulin-like growth factor I receptor. J Clin Endocrinol Metab 2006;91:3062-3070. Epub 2006 Jun 6

11. Klammt J, Kiess W, Pfäffle R. IGF1R mutations as cause of SGA. Best Pract Res Clin Endocrinol Metab 2011;25:191-206.

12. Clayton PE, Cianfarani S, Czernichow P, Johannsson G, Rapaport R, Rogol A. Management of the child born small for gestational age through adulthood: a consensus statement of the International Societies of Pediatric Endocrinology and the Growth Hormone Research. J Clin Endocrinol Metab 2007;92:804-810. Epub 2007 Jan 2

13. Hokken-Koelega AC, De Ridder MA, Lemmen RJ, Den Hartog H, De Muinck Keizer-Schrama SM, Drop SL. Children born small for gestational age: do they catch up? Pediatr Res 1995;38:267-271.

14. Albertsson-WiklandK, Karlberg J. Postnatal growth of children born small for gestational age. Acta Paediatr Suppl 1997;423:193-195.

15. Stalman SE, Solanky N, Ishida M, Alemán-Charlet C, Abu-Amero S, Alders M, Alvizi L, Baird W, Demetriou C, Henneman P, James C, Knegt LC, Leon LJ, Mannens MMAM, Mul AN, Nibbering NA, Peskett E, Rezwan FI, Ris-Stalpers C, van der Post JAM, Kamp GA, Plötz FB, Wit JM, Stanier P, Moore GE, Hennekam RC. Genetic Analyses in Small-forGestational-Age Newborns. J Clin Endocrinol Metab 2018;103:917-925.

16. Müller E, Dunstheimer D, Klammt J, Friebe D, Kiess W, Kratzsch J, Kruis T, Laue S, Pfäffle R, Wallborn T, Heidemann PH. Clinical and functional characterization of a patient carrying a compound heterozygous pericentrin mutation and a heterozygous IGF1 receptor mutation. PLoS One 2012;7:e38220. Epub 2012 May 31

17. Juez G, Lucero E, Ventura-Juncá P, Tapia J, González H, Winter A. Intrauterine growth in Chilean middle class newborn infants. Rev Chil Pediatr 1989;60:198-202

18. Youlton R, Valenzuela C. Growth patterns in height and weight in children aged 0 to 17 years and cranial circumference in children aged 0 to 2 years from medium-high and high socioeconomic status in Santiago. Comparison with growth in children from medium-low and low status in the Northern area of Santiago. Rev Chil Pediatr 1990:122.

19. Kuczmarski RJ, Ogden CL, Guo SS, Grummer-Strawn LM, Flegal KM, Mei Z, Wei R, Curtin LR, Roche AF, Johnson CL. 2000 CDC growth charts for the United States: Methods and development. Vital Health Stat 11 2002:1-190.

20. Fang P, Schwartz ID, Johnson BD, Derr MA, Roberts CT Jr, Hwa V, Rosenfeld RG. Familial short stature caused by haploinsufficiency of the insulin-like growth factor $\mathrm{i}$ receptor due to nonsensemediated messenger ribonucleic acid decay. J Clin Endocrinol Metab 2009;94:1740-1747. Epub 2009 Feb 24

21. Raile K, Klammt J, Schneider A, Keller A, Laue S, Smith R, Pfäffle R, Kratzsch J, Keller E, Kiess W. Clinical and functional characteristics of the human Arg59Ter insulin-like growth factor 1 receptor (IGF1R) mutation: implications for a gene dosage effect of the human IGF1R. J Clin Endocrinol Metab 2006;91:2264-2271. Epub 2006 Mar 28

22. Kawashima Y, Kanzaki S, Yang F, Kinoshita T, Hanaki K, Nagaishi J, Ohtsuka Y, Hisatome I, Ninomoya H, Nanba E, Fukushima T, Takahashi $\mathrm{S}$. Mutation at cleavage site of insulin-like growth factor receptor in a short-stature child born with intrauterine growth retardation. J Clin Endocrinol Metab 2005;90:4679-4687. Epub 2005 May 31
23. Wallborn T, Wüller S, Klammt J, Kruis T, Kratzsch J, Schmidt G, Schlicke M, Müller E, van de Leur HS, Kiess W, Pfäffle R. A heterozygous mutation of the insulin-like growth factor-I receptor causes retention of the nascent protein in the endoplasmic reticulum and results in intrauterine and postnatal growth retardation. J Clin Endocrinol Metab 2010;95:2316-2324. Epub 2010 Mar 31

24. Rosenfeld RG. Insulin-like growth factors and the basis of growth. N Engl J Med 2003;349:2184-2186.

25. Inagaki K, Tiulpakov A, Rubtsov P, Sverdlova P, Peterkova V, Yakar S, Terekhov S, LeRoith D. A familial insulin-like growth factor-I receptor mutant leads to short stature: clinical and biochemical characterization. J Clin Endocrinol Metab 2007;92:1542-1548. Epub 2007 Jan 30

26. Kruis T, Klammt J, Galli-Tsinopoulou A, Wallborn T, Schlicke M, Müller E, Kratzsch J, Körner A, Odeh R, Kiess W, Pfäffle R. Heterozygous mutation within a kinase-conserved motif of the insulin-like growth factor I receptor causes intrauterine and postnatal growth retardation. J Clin Endocrinol Metab 2010;95:1137-1142. Epub 2010 Jan 26

27. Fang P, Cho YH, Derr MA, Rosenfeld RG, Hwa V, Cowell CT. Severe short stature caused by novel compound heterozygous mutations of the insulin-like growth factor 1 receptor (IGF1R). J Clin Endocrinol Metab 2012;97:243-247. Epub 2011 Nov 30

28. Harmel EM, Binder G, Barnikol-Oettler A, Caliebe J, Kiess W, Losekoot M, Ranke MB, Rappold GA, Schlicke M, Stobbe H, Wit JM, Pfäffle R, Klammt J. Alu-mediated recombination defect in IGF1R: haploinsufficiency in a patient with short stature. Horm Res Paediatr 2013;80:431-442. Epub 2013 Nov 26

29. Leal AC, Montenegro LR, Saito RF, Ribeiro TC, Coutinho DC, Mendonca $\mathrm{BB}$, Arnhold IJ, Jorge AA. Analysis of the insulin-like growth factor 1 receptor gene in children born small for gestational age: in vitro characterization of a novel mutation (p.Arg511Trp). Clin Endocrinol (Oxf) 2013;78:558-563

30. Kawashima Y, Hakuno F, Okada S, Hotsubo T, Kinoshita T, Fujimoto M, Nishimura R, Fukushima T, Hanaki K, Takahashi S, Kanzaki S. Familial short stature is associated with a novel dominant-negative heterozygous insulin-like growth factor 1 receptor (IGF1R) mutation. Clin Endocrinol (Oxf) 2014;81:312-314. Epub 2013 Sep 30

31. Labarta JI, Barrio E, Audi L, Fernández-Cancio M, Andaluz P, de Arriba A, Puga B, Calvo MT, Mayayo E, Carrascosa A, Ferrández-Longás A. Familial short stature and intrauterine growth retardation associated with a novel mutation in the IGF-I receptor (IGF1R) gene. Clin Endocrinol (Oxf) 2013;78:255-262.

32. Burkhardt S, Gesing J, Kapellen TM, Kovacs P, Kratzsch J, Schlicke M, Stobbe H, Tönjes A, Klammt J, Pfäffle R. Novel heterozygous IGF1R mutation in two brothers with developing impaired glucose tolerance. J Pediatr Endocrinol Metab 2015;28:217-225.

33. Ocaranza P, Golekoh MC, Andrew SF, Guo MH, Kaplowitz P, Saal H, Rosenfeld RG, Dauber A, Cassorla F, Backeljauw PF, Hwa V. Expanding genetic and functional diagnoses of IGF1R haploinsufficiencies. Horm Res Paediatr 2017;87:412-422. Epub 2017 Apr 10

34. Solomon-Zemler R, Basel-Vanagaite L, Steier D, Yakar S, Mel E, Phillip M, Bazak L, Bercovich D, Werner H, de Vries L. A novel heterozygous IGF-1 receptor mutation associated with hypoglycemia. Endocr Connect 2017;6:395-403. Epub 2017 Jun 25

35. Gannagé-Yared MH, Klammt J, Chouery E, Corbani S, Mégarbané H, Aboughoch J, Choucair N, Pfäffle R, Mégarbané A. Homozygous mutation of the IGF1 receptor gene in a patient with severe pre- and postnatal growth failure and congenital malformation. Eur J Endocrinol 2012:168:1-7

36. Prontera P, Micale L, Verrotti A, Napolioni V, Stangoni G, Merla G. A New Homozygous IGF $1 \mathrm{R}$ variant defines a clinically recognizable incomplete 
dominant form of SHORT Syndrome. Hum Mutat 2015;36:1043-1047. Epub 2015 Aug 24

37. Ester WA, van Duyvçenvoorde HA, de Wit CC, Broekman AJ, Ruivenkamp CA, Govaerts LC, Wit JM, Hokken-Koelega AC, Losekoot M. Two short children born small for gestational age with insulin-like growth factor 1 receptor haploinsufficiency illustrate the heterogeneity of its phenotype. J Clin Endocrinol Metab 2009;94:4717-4727. Epub 2009 Oct 28

38. David A, Hwa V, Metherell LA, Netchine I, Camacho-Hübner C, Clark AJ, Rosenfeld RG, Savage MO. Evidence for a continuum of genetic, phenotypic, and biochemical abnormalities in children with growth hormone insensitivity. Endocr Rev 2011;32:472-497. Epub 2011 Apr 27 